\title{
Diffusion of landfill leachate through compacted natural clays containing small amounts of carbonates and sulfates
}

\author{
Isabel S. De Soto ${ }^{\mathrm{a}, *}$, Ana I. Ruiz ${ }^{\mathrm{a}}$, Carlos Ayora ${ }^{\mathrm{b}}$, Rosario García ${ }^{\mathrm{a}}$, Mercedes Regadio a , Jaime Cuevas ${ }^{\mathrm{a}}$ \\ ${ }^{a}$ Departamento de Geología y Geoquímica, Facultad de Ciencias, Universidad Autónoma de Madrid, Campus de Cantoblanco, 28049 Madrid, Spain \\ ${ }^{\mathrm{b}}$ Instituto de Diagnostico Ambiental y Estudios del Agua, Consejo Superior de Investigaciones Científicas, 08034 Barcelona, Spain
}

\section{A R T I C L E I N F O}

\section{Article history:}

Received 8 July 2011

Accepted 23 February 2012

Available online 8 March 2012

Editorial handling by R. Fuge

\begin{abstract}
A B S T R A C T
Diffusion of a synthetic urban landfill leachate through compacted natural illitic clays and the role of reactive accessory minerals (carbonates and gypsum) in the geochemical behavior of major soluble ions are evaluated. The leachate is composed of $\mathrm{NH}_{4}^{+}$and $\mathrm{Na}^{+}(0.25 \mathrm{M})$ balanced by $\mathrm{Cl}^{-}(0.25 \mathrm{M})$, acetate $(0.1 \mathrm{M})$ and $\mathrm{HCO}_{3}^{-}(0.15 \mathrm{M})$. The $\mathrm{pH}$ is 7.8 and it is typical of the mature stage of organic matter degradation within an urban landfill. Laboratory scale diffusion tests were performed over 4 months (long term experiment, LT) and 2 weeks (short term experiment, ST). The ST experiments were designed to allow the measurement of the $\mathrm{Cl}^{-}$gradient as a diffusion tracer in the compacted clay. In the LT experiments the chemical gradients were already at steady state, but geochemical reactions involving dissolution of gypsum and precipitation of calcite were observed. Evolution of pore-water chemistry, mineralogy, cation exchange properties, and the specific surface of clays were determined. Numerical simulations were carried out using the geochemical code RETRASO. Chloride transport, precipitation of carbonates, $\mathrm{pH}$ buffering, and $\mathrm{Ca}^{2+} / \mathrm{NH}_{4}^{+}$cation exchange reactions took place in the laboratory tests. Apparent $\mathrm{Cl}^{-}$diffusion coefficients were determined by direct modeling of the ST tests and validated with the LT experiments. These coefficients were considered in the simulation of transport coupled with experimentally calculated exchange constants and dissolution/precipitation reactions of gypsum and carbonates. Sulfate reduction coupled with acetate oxidation has been proven to be relevant in the sample with significant concentration of $\mathrm{SO}_{4}^{2-}$ (Bailén). This process also includes significant precipitation of carbonates (mainly calcite) and causes a decrease of $\mathrm{SO}_{4}^{2-}$ in the porewater.
\end{abstract}

(c) 2012 Elsevier Ltd. All rights reserved.

\section{Introduction}

The adequate performance of landfills requires an engineered liner system to protect groundwater and surface resources. Compacted clay materials are used in these engineered liners due to special properties like low porosity, low hydraulic conductivity (Rowe et al., 1995), slow diffusive transport and high capacity of cation adsorption (Bourg et al., 2003). They are commonly called clay barriers.

Physical movement of dissolved species through soils is mainly governed by two processes: diffusion and advection. However, in the case of clay barriers, their low permeability renders advection negligible. Therefore, diffusion is identified as the major transport process in compacted clay material (Rosanne et al., 2003).The process is described by Fick's law which relates the flux of a chemical to its concentration gradient;

\footnotetext{
* Corresponding author. Tel.: +34 9149750 63; fax: +34 914974900 .

E-mail addresses: isabel.desoto@uam.es, isabel.desoto1@gmail.com (I.S. De Soto).
}

$F=-D_{e} \frac{\partial c}{\partial x}$

where $F$ is the flux ( $\left.\mathrm{mol} / \mathrm{s} / \mathrm{m}^{2}\right), D_{e}$ the effective diffusion coefficient $\left(\mathrm{m}^{2} / \mathrm{s}\right.$ ), and $c$ the concentration $\left(\mathrm{mol} / \mathrm{m}^{3}\right)$ (Foged and Baumann, 1999; Appelo and Postma, 2005; Tanhua-Tyrkkö, 2009).

For chemical species which are not retarded by adsorption (e.g. $\mathrm{Cl}^{-}$), the $D_{e}$ can be related to the diffusion coefficient of the species in free water at standard temperature and pressure conditions, $D_{w}$. $D_{e}=D_{w} \tau n$

where $\tau$ is the tortuosity and $n$ is the porosity of the clay sample. The combined parameter, $\tau n$, is often referred to as effective porosity (Foged and Baumann, 1999). Solute transport through clay barriers is not solely governed by physical processes, but also by geochemical reactions. Therefore, many studies on transport of solutes through clay barriers focus on how geochemical reactions such as redox reactions, precipitation of minerals, ion-exchange and anion exclusion, affect the confinement properties of clay barriers (Montes-H et al., 2005; Van Loon et al., 2007; Appelo et al., 2010).

Precipitation of minerals in the landfill barrier produces a reduction of clay porosity and for the specific case of carbonates, contributes to $\mathrm{pH}$ buffering. Evolution of initial leachate has been 
linked to the degradation of volatile fatty acids (VFAs), primarily acetate $\left(\mathrm{CH}_{3} \mathrm{COO}^{-}\right)$, and is characterized by an increase of carbonate concentration and $\mathrm{pH}$ values, which may drive $\mathrm{CaCO}_{3}$ precipitation (VanGulck and Rowe, 2004b). The development of inorganic clogging material (mainly $\mathrm{CaCO}_{3}$ ) is responsible for changing the clay barrier properties by reducing the pore volume and hydraulic conductivity (Islam and Singhal, 2004; VanGulck and Rowe, 2004a,b).

Compacted clays contain swelling minerals (smectites), nonswelling minerals (such as quartz, calcite and feldspar) and voids (Komine and Ogata, 1996). Swelling process in smectite clay minerals is one of the main mechanisms for changes in porosity/water content. These materials increase their volume when water is added. Water molecules are adsorbed at active sites on the smectites causing it to expand by increasing the interlayer space. The ability of swelling is related to the layered structure of the mineral (Kraehenbuehl et al., 1987; Spooner and Giusti, 1999; Pusch, 2006).

The permanent negative charge on clay surfaces and its associated cation exchange capacity (CEC) influences the behavior of cations in landfill areas (Christensen et al., 2000). When a saline solution is in contact with compacted clays, exchange capacity is the main mechanism used by cations to enter in clay barriers (Birgersson and Karnland, 2009). For this reason, in landfill areas, monovalent cations, such as, $\mathrm{Na}^{+}$and $\mathrm{NH}_{4}^{+}$are moderately attenuated compared to $\mathrm{Cl}^{-}$(Malusis et al., 2003). Desorption of $\mathrm{Ca}^{2+}$ and $\mathrm{Mg}^{2+}$ from the original clay occurs during the adsorption of $\mathrm{NH}_{4}^{+}$ from the leachate (Thornton et al., 2000; Pivato and Raga, 2006) due to the affinity of $\mathrm{NH}_{4}^{+}$, at high concentration, for the cation exchange positions (Pivato and Raga, 2006). This affinity is favoured also by the existence of frayed edge sites of illites, which are predominantly accessible to cations with low hydratation energies such as $\mathrm{NH}_{4}^{+}$(Bradbury and Baeyens, 2000). Thus, variations in the exchangeable cations are produced, as a consequence of changes in the initial soluble cation concentrations of the porewater. An increase of $\mathrm{Ca}^{2+}$ in the porewater could produce calcite precipitation. Anion exclusion occurs in the interlayer pores of smectites (Bradbury and Baeyens, 2003) due to the electrostatic repulsions between anions and the negatively charged clay surfaces (Molera et al., 2003; Smith et al., 2004). This phenomenon is relevant in bentonite materials, which often behave as semipermeable membranes for anions (Malusis et al., 2003; Kang and Shackelford, 2010). As a consequence $\mathrm{Cl}^{-}$in compacted bentonite is concentrated in the interparticle pore space. The extent of this phenomenon is strongly related to the dry density of the material. At high dry densities, the effective diffusion is smaller than at low dry densities, because in a compacted bentonite, the interparticle space decreases more so than the inter-lamellar volume. The diffusion of $\mathrm{Cl}^{-}$through a compacted bentonite also depends on the chemical composition of the pore water. At high pore water ionic strength, the $\mathrm{Cl}^{-}$-accessible pore space (interparticle pore space) is larger than at low ionic strength (Van Loon et al., 2007).

Diffusion experiments were performed in the laboratory in order to evaluate the effects of leachates on natural compacted clay materials used as engineered barriers. Modelling was carried out using a geochemical transport model which included geochemical and effective porosity changes. This paper presents the results and modelling of laboratory tests performed through natural compacted clays from two Spanish deposits, normally used for ceramic raw materials, composed of illite and small amounts of smectite.

\section{Materials and methods}

Tests were performed using two different Spanish ceramic clays, Bailén and El Papiol, with hydraulic conductivity (HC) values of $1.9( \pm 0.2) \times 10^{-10}$ and $5.2( \pm 0.2) \times 10^{-10} \mathrm{~m} / \mathrm{s}$ (Rogel et al., 2009) measured at Proctor compaction dry densities of $1.9( \pm 0.1)$ and 2.0
$( \pm 0.1) \mathrm{kg} / \mathrm{dm}^{3}$, respectively. The HC were lower than $1 \times 10^{-9} \mathrm{~m} / \mathrm{s}$, the highest permeability allowed by Spanish regulations for liner shields (Real Decreto 1481/2001). Bailén (Jaén, Spain) clay is of Miocene age (González et al., 1998) and is composed of illite, smectite, kaolinite, carbonates, quartz, feldspar and pyrite. El Papiol (Barcelona, Spain) clay is a Pliocene heterogeneous material composed of illite, chlorite, smectite, carbonates, quartz, feldspar and hematite (Table 1) (Cuevas et al., 2012).

\subsection{Diffusion tests}

Laboratory scale diffusion tests were performed over 4 months (long term experiment, LT) and 2 weeks (short term experiment, ST). In fact, the ST experiments were designed to allow the measurement of the $\mathrm{Cl}^{-}$gradient in the compacted clay, because in the LT experiments the chemical gradients were already at steady state.

The tests consisted of diffusion of a synthetic leachate (Table 2) through a disc of compacted clay. The compacted clay was compacted into a cylindrical column $(2.1 \mathrm{~cm}$ height and $7 \mathrm{~cm}$ diameter $)$ and was inserted inside a Teflon sleeve into a steel body to avoid clay deformation. Then, distilled water and the synthetic leachate were circulated through two porous Teflon filters at either end of the cylindrical clay column interface (Fig 1).

The experiment was carried out in three steps:

1) Stabilization step: Water was circulated at the bottom of the cell over two mouths (LT experiments) or 1 week (ST experiment).

2) Diffusion step: Water (at the bottom of the cell) and synthetic leachate (at the top of the cell) were circulated over 2 months (LT experiments) or for 1 week (ST experiments).

3) Analysis step: Compacted clay columns were withdrawn from the teflon cells. The clay material was cut into three discs of $7 \mathrm{~mm}$ thickness (S1, S2 and S3, where S1 is the contact between leachate and clay and S3 is the contact area between water and clay) in order to characterize mineralogy and physico-chemical properties.

During the first and second steps, electric conductivity (EC) was measured daily in the water container using a Metrohm ${ }^{\mathrm{TM}}$ AG 9101 conductivity cell.

\subsection{Analytical methods}

Mineralogical characterization was carried out by X-ray diffraction (XRD) using a PANalyticalX́Pert PRO diffractometer with $\mathrm{Ge}(111)$ as the primary monochromator, CuK $\alpha 1$ radiation and an X'Celerator detector. The samples, prepared for the random powder method, were recorded over the range $3<2 \theta<70^{\circ}$ with a step size of $0.0167^{\circ}$ and a counting time of $100 \mathrm{~s}$ for each step. Mineralogy was studied by XRD, and for data analysis the DRXWIN software (Primo Martín, 2002) was used. To semi-quantify the minerals in the bulk sample, the method proposed in

Table 1

Initial mineralogy of Bailén and El Papiol clays.

\begin{tabular}{lllllllllll}
\hline \multirow{2}{*}{ Clays } & \multicolumn{3}{l}{ Sheet-silicates } & & \multirow{2}{*}{ Qtz } & Pl & Kfs & Cal & Dol & Others \\
\cline { 2 - 5 } & T & Kln & Ill & Sm & & & & & & \\
\hline Bailén & 52 & 7 & 33 & 12 & 30 & 1 & $<1$ & 11 & 5 & Py: 1 \\
El Papiol & 58 & - & 33 & 16 & 30 & 1 & 1 & 6 & 2 & Hem: 2 \\
& & & & & & & & & & Chl: 9
\end{tabular}

T: total sheet-silicates content; Kln: kaolinite; Ill: illite; Sm: smectite; Chl: chlorite; Qtz: quartz; Pl: plagioclase; Kfs: K-feldspar; Cal: calcite; Dol: dolomite; Hem: hematite; Py: pyrite. 
Table 2

$\mathrm{pH}$ and chemical composition (mol/L) of different leachates: El Garraf leachate and the synthetic leachate used in the diffusion tests.

\begin{tabular}{lll}
\hline & El Garraf leachate & Synthetic leachate \\
\hline $\mathrm{pH}$ & 8.60 & 7.78 \\
$\mathrm{CH}_{3} \mathrm{COO}^{-}$ & $0.039^{*}$ & 0.10 \\
$\mathrm{HCO}_{3}^{-}$ & $0.293^{* *}$ & 0.15 \\
$\mathrm{Cl}^{-}$ & 0.253 & 0.25 \\
$\mathrm{NH}_{4}^{+}$ & 0.254 & 0.25 \\
$\mathrm{Na}^{+}$ & 0.196 & 0.25 \\
$\mathrm{~K}^{+}$ & 0.059 & - \\
$\mathrm{Ca}^{2+}$ & $1.25 \times 10^{-4}$ & - \\
$\mathrm{Mg}^{2+}$ & 0.005 & -
\end{tabular}

* Calculated as $\mathrm{CH}_{3} \mathrm{COO}^{-}$from TOC analysis.

** Calculated as $\mathrm{HCO}_{3}^{-}$from total alkalinity.

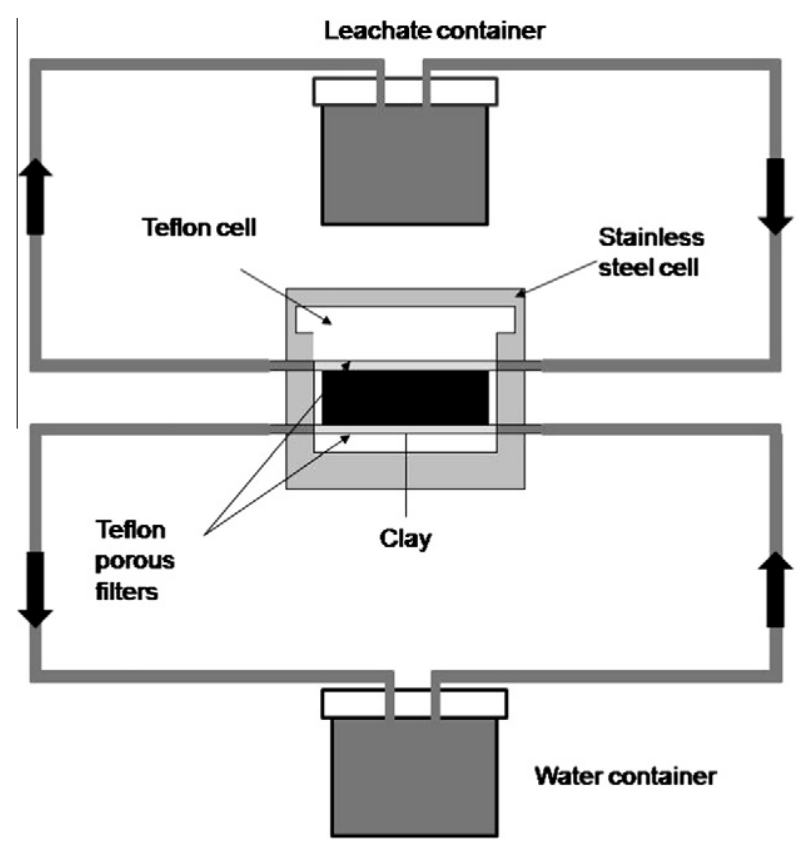

Fig. 1. Schematic of the diffusion tests carried out in the laboratory.

Schultz (1964) was used, described also in UNE 22-161-92. Samples were previously dried at $105{ }^{\circ} \mathrm{C}$ and ground in a Retsch ${ }^{\mathrm{TM}}$ MM200 microball mill for $5 \mathrm{~min}$ at a frequency of $1 / 25 \mathrm{~s}^{-1}$. To compare and to check differences between the very similar random powder diffraction patterns obtained, $10 \%$ of $\mathrm{ZnO}$ was mixed as an internal standard with the bulk sample (Srodon et al., 2001): $1 \mathrm{~g}$ of ground sample and $0.1 \mathrm{~g} \mathrm{ZnO}$. Although a $10 \%$ relative error is assumed for this semi quantitative method, the relative differences between samples could be evaluated when pattern profiles were represented together. In addition, longitudinal $10 \mathrm{~mm} \mathrm{sec-}$ tions of the compacted clay were cut off and embedded in a LRWHITE Resin (Cobeña et al., 1999).Thin section petrographic analysis were carried out with a Petrographic Polarization Orto Plan Pol Leitz Microscope. The sections were also polished and studied using a Philips-XL 30 scanning electron microscope combined with EDX (SEM-EDX).

Specific surface area was measured in order to obtain textural information of the clays. The $\mathrm{N}_{2}$ BET surface was determined in a GEMINI V micrometrics ${ }^{\circledR}$ porosimeter after degassing under a $\mathrm{N}_{2}$ flow over $18 \mathrm{~h}$ at $90^{\circ} \mathrm{C}$ (UNE 22-164/94).

Initial porewater of both original clay materials was extracted by squeezing at laboratory conditions $\left(25^{\circ} \mathrm{C}\right)$ and the soluble ion concentration was measured by ion chromatography (Metrohm ${ }^{\mathrm{TM}}$ 882 Compact IC). The water extracted by squeezing was never in contact with the atmosphere to avoid alkalinity alteration. These analyses were used to calculate the exchange constants for the cation exchange reactions and the initial saturation indexes for carbonates and sulfates.

Soluble salts in the experiments were measured in a 1:20 aqueous extract instead of using the squeezing method due to the small amount of available sample $(<30 \mathrm{~g})$. The aqueous extracts were performed with the sampled clays after diffusion tests using the methodology proposed by Cuevas et al. (1997). Concentrations of cations and anions were also determined by ion chromatography. These analyses cannot be used to calculate equilibrium conditions because of the artifacts introduced by the dissolution of carbonates and sulfates. They are used to evaluate only the anion diffusion after applying a concentration factor to calculate the actual porewater concentration. Concentrations of $\mathrm{SO}_{4}^{2-}$ and $\mathrm{Cl}^{-}$in the water container at the end of the tests were also measured.

Exchangeable cations were extracted from the clay at room temperature using the methodology proposed by Thomas (1982). The $\mathrm{NH}_{4}$ was determined by ion selective potentiometry (ORION ${ }^{\mathrm{TM}}$ 9512 Ammonia Gas Sensing Electrode), Na and K using a Buck Scientific ${ }^{\circledR}$ PFP-7 flame photometer and finally, Ca and Mg by Atomic Absorption (Unicam ${ }^{\mathrm{TM}}$ Solaar M). Cation exchange capacity (CEC) was determined by the methodology proposed by Rhoades (1982) $\left(\mathrm{Na}^{+}\right.$homoionization, $\mathrm{Na}-\mathrm{COO}-\mathrm{CH}_{3} 1 \mathrm{M}, \mathrm{pH}=8$, and $\mathrm{Mg}^{2+}$ displacement, $\mathrm{MgNO}_{3} \cdot 5 \mathrm{H}_{2} \mathrm{O} 0.5 \mathrm{M}$ at $\mathrm{pH}=5$ ).

\section{Geochemical model}

Equilibrium and kinetic processes are considered to simulate the geochemical behavior of compacted clays during the diffusion experiments. Equilibrium processes described by mass action laws are sufficiently fast with respect to transport (diffusion), such as aqueous speciation and ion-exchange reactions. In contrast, kinetic processes are slower than fluxes and they may never reach equilibrium, such as oxidation-reduction reactions and dissolution-precipitation of minerals.

The code "Retraso" (Saaltink et al., 2004) was used for the simulation of reactive diffusion experiments. The PHREEQC thermodynamic and kinetic data base was used for the calculations (Parkhurst and Appelo, 1999). ST tests performed in both clays were first modeled in order to describe $\mathrm{Cl}^{-}$transport, $\mathrm{SO}_{4}$-reduction, exchangeable cations distribution and carbonate dissolution/precipitation. The models were carried out in two steps of 1 week duration which correspond to the steps of the diffusion experiment:

1) Stabilization step simulated by 13 cells of different thickness, mineralogy and chemical composition ( 1 water cell, 1 Teflon porous filter cell and 11 clay cells) (Fig. 2a).

2) Diffusion step simulated by 15 different cells ( 1 water cell, 2 Teflon porous filter cells, 1 leachate cell and 11 clay cells) (Fig. 2b). LT test were modeled after the ST using the same boundary conditions and by just changing the time (2 months).

The modeling results for the chemistry of the clay porewater obtained in the stabilization step were the initial values used in the second step of the simulation.

Dolomite was assumed to dissolve according to the kinetic law described by Chou et al. (1989), and calcite was assumed to precipitate rapidly at equilibrium. Minerals with slow dissolution kinetics such as quartz, clays and feldspars were not included in the model and they were considered to be non-reactive at the time scale of the experiments (Drever, 1998).

Cation exchange was calculated from the measured CEC and initial composition of the exchange complex. Exchange reactions 

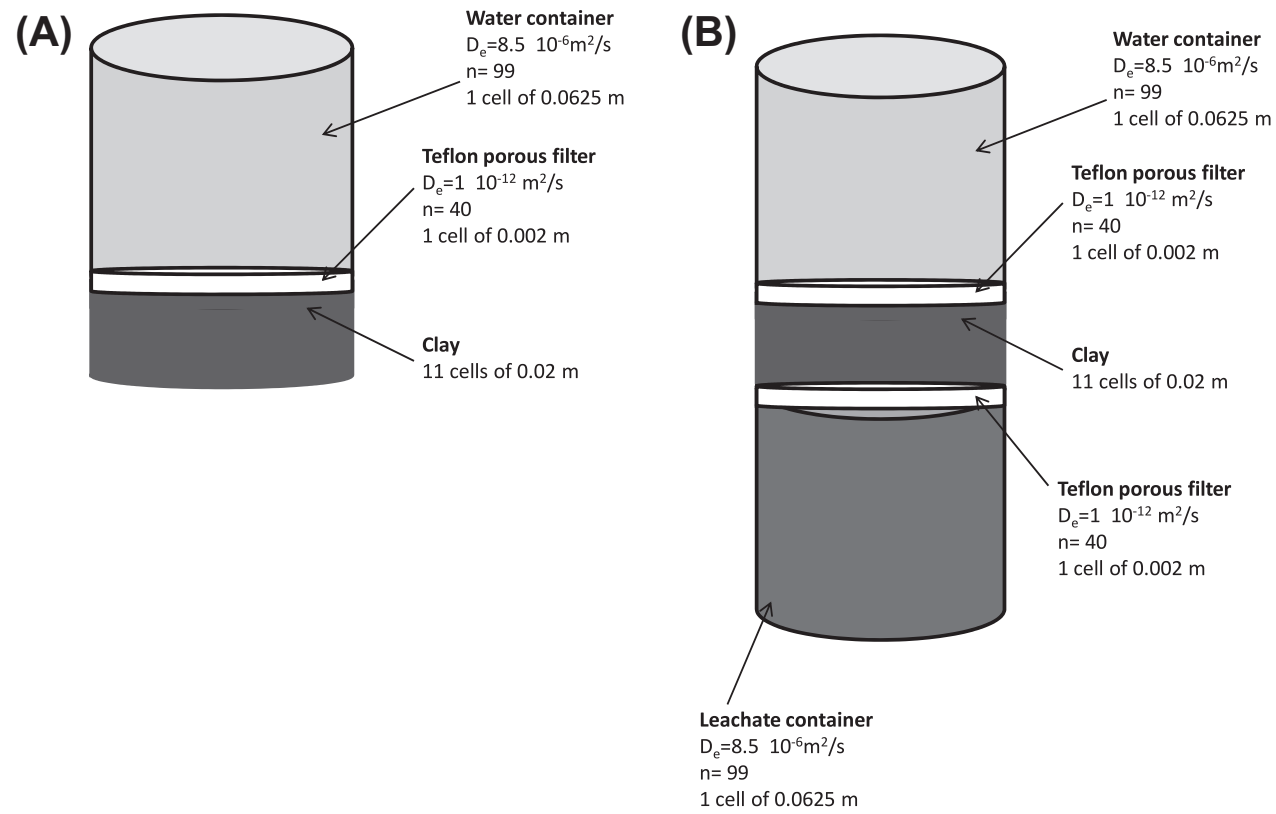

Fig. 2. Schematic of the simulation. (A) Stabilization step. (B) Diffusion step.

were formulated according to the Gaines-Thomas convention (Saaltink et al., 2004; Appelo and Postma, 2005):

$\frac{1}{z_{i}} I^{z_{i}}+\frac{1}{z_{j}}\left(X_{z_{j}}-J\right)=\frac{1}{z_{i}}\left(X_{z_{i}}-I\right)+\frac{1}{z_{j}} J^{z_{j}}$

where $z$ is the electric charge of the cation. The expression $\left(X_{z}-I\right)$ indicates that each exchangeable cation occupies $z$ exchangeable sites. According to this convention the activity of an exchangeable cation is approximated to its equivalent fraction:

$a\left(X_{z i}-I\right)=\beta_{I}=\frac{\left[X_{z i}-I\right]_{\mathrm{eq}}}{\sum_{J=1}^{J=N_{\gamma}}\left[X_{z i}-I\right]_{\mathrm{eq}}}=\frac{Z_{I}\left[X_{z i}-I\right]_{M}}{\mathrm{CEC}}$

where $\left[X_{z i}-I\right]_{e q}$ and $\left[X_{z i}-I\right]_{M}$ are the number of equivalents and moles of the exchangeable cation per $\mathrm{kg}$ of water, respectively; $\beta_{I}$ is the equivalent fraction, CEC is the cation exchange capacity, and $N_{Y}$ the total number of exchangeable cations. The exchange coefficient for the reaction under the Gaines-Thomas convention is:

$K_{I / J}=\frac{a_{j}^{\frac{1}{z_{j}}} \beta_{I}^{\frac{1}{z_{i}}}}{a_{i}^{\frac{1}{z_{i}}} \beta_{J}^{\frac{1}{z_{j}}}}$

The value of the exchange coefficients for both Bailén and El Papiol clay were calculated from the initial composition of the exchange complex and the initial pore water (extracted by squeezing), with the exception of the $\mathrm{NH}_{4}^{+}$exchange coefficient. This constant was calculated from Bailén clay data obtained by porewater squeezing extraction and subsequent exchangeable cation displacement in a 4-a leachate diffusion column $(0.5 \mathrm{~m}$ thickness) experiments (Hervás et al., 2010). The same $\mathrm{NH}_{4}^{+}$ constant was used for both clays. Cation exchange coefficients of Bailén clay are similar to PHREEQC database constants (Table 3). However, in El Papiol clay constants differ. The new calculated exchange coefficients better approached the exchangeable cation results for both Bailén and El Papiol than the general PHREEQC constants and were used in the modeling trials.

Finally, $\mathrm{SO}_{4}$-reduction by dissolved organic $\mathrm{C}$ was considered in the model as:

$2 \mathrm{CH}_{2} \mathrm{O}+\mathrm{SO}_{4}^{2-} \rightarrow \mathrm{H}_{2} \mathrm{~S}+2 \mathrm{HCO}_{3}^{-}$

First order kinetics with a rate constant of $2.5 \times 10^{-5} \mathrm{~s}^{-1}$ (Rolle et al., 2008) was assumed for $\mathrm{SO}_{4}$-reduction.
Table 3

Exchange coefficient $(\log K)$ calculated for Bailén and El Papiol. Comparison with values given in PHREEQC database (Parkhurst and Appelo, 1999).

\begin{tabular}{llll}
\hline & Bailén & El Papiol & PHREEQC \\
\hline $\mathrm{NaX}$ & 0 & 0 & 0 \\
$\mathrm{KX}$ & -0.42 & -1.92 & -0.70 \\
$\mathrm{CaX}$ & -0.90 & -1.13 & -0.60 \\
$\mathrm{MgX}_{2}$ & -0.80 & -0.99 & -0.60 \\
\hline
\end{tabular}

\section{Initial and boundary conditions}

\subsection{Initial clay porewater composition and $\mathrm{pH}$}

The concentration of ions in the initial porewater in the studied clays conditioned the diffusion of soluble salts through the compacted clay material. Bailén initial porewater is characterized by a high soluble salt content. Calcium, $\mathrm{Mg}, \mathrm{SO}_{4}$ and $\mathrm{Cl}$ are the dominant soluble components. Saturation Indexes (SI) of calcite, disordered dolomite and gypsum have been computed using PHREEQC software version 2.17 (Parkhurst and Appelo, 1999). Undersaturation of the solution with respect to dolomite was found for Bailén porewater, whereas gypsum and calcite are virtually at equilibrium ( $\mathrm{SI}=0.09$ and 0.02 , respectively). In El Papiol clay, undersaturation of the initial porewater with respect to these sparingly soluble minerals was also computed (Table 4). Textural differences between the clays regarding carbonates are the existence of fine grained carbonates in Bailén clay and coarse grains in El Papiol clay. The coarse grains are not as rapidly dissolved compared to fine grains during the aqueous extraction of porewater. For this reason El Papiol clay porewater shows an undersaturation condition with respect to calcite.

In Bailén clay, there is a $5.3 \times 10^{-4} \mathrm{~mol} / \mathrm{L}$ concentration of gypsum that precipitates due to the amount of $\mathrm{Ca}$ and $\mathrm{SO}_{4}$ in the pore water. Due to this small amount of gypsum ( $<5 \%$ solid weight), this mineral is not recorded by DRX techniques (Table 1 ).

$\mathrm{pH}$ values in the initial clays obtained by squeezing were 7.5 in Bailén and 7.2 in El Papiol clay (Table 4). It is worth mentioning that $\mathrm{pH}$ values are higher in the 1:20 aqueous extracts (7.7 in Bailén and 9.6 in El Papiol; not shown). This $\mathrm{pH}$ increase is produced by the dissolution of carbonates during the aqueous 
Table 4

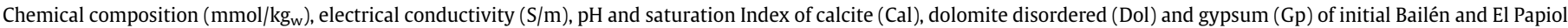
porewater.

\begin{tabular}{|c|c|c|c|c|c|c|c|c|c|c|c|c|c|}
\hline \multirow[t]{2}{*}{ Clay } & \multirow{2}{*}{$\begin{array}{l}\mathrm{Na} \\
\left(\mathrm{mmol} / \mathrm{kg}_{\mathrm{w}}\right)\end{array}$} & \multirow{2}{*}{$\begin{array}{l}\mathrm{K} \\
\left(\mathrm{mmol} / \mathrm{kg}_{\mathrm{w}}\right)\end{array}$} & \multirow{2}{*}{$\begin{array}{l}\mathrm{NH}_{4} \\
\left(\mathrm{mmol} / \mathrm{kg}_{\mathrm{w}}\right)\end{array}$} & \multirow{2}{*}{$\begin{array}{l}\mathrm{Ca} \\
\left(\mathrm{mmol} / \mathrm{kg}_{\mathrm{w}}\right)\end{array}$} & \multirow{2}{*}{$\begin{array}{l}\mathrm{Mg} \\
\left(\mathrm{mmol} / \mathrm{kg}_{\mathrm{w}}\right)\end{array}$} & \multirow{2}{*}{$\begin{array}{l}\mathrm{Cl} \\
\left(\mathrm{mmol} / \mathrm{kg}_{\mathrm{w}}\right)\end{array}$} & \multirow{2}{*}{$\begin{array}{l}\mathrm{SO}_{4} \\
\left(\mathrm{mmol} / \mathrm{kg}_{\mathrm{w}}\right)\end{array}$} & \multirow{2}{*}{$\begin{array}{l}\mathrm{H}_{2} \mathrm{CO}_{3} \\
\left(\mathrm{mmol} / \mathrm{kg}_{\mathrm{w}}\right)\end{array}$} & \multirow{2}{*}{$\begin{array}{l}\mathrm{EC} \\
(\mathrm{S} / \mathrm{m})\end{array}$} & \multirow{2}{*}{$\begin{array}{l}\mathrm{pH} \\
(\mathrm{S} / \mathrm{m})\end{array}$} & \multicolumn{3}{|c|}{ Saturation Index } \\
\hline & & & & & & & & & & & Cal & Dol & Gp \\
\hline Bailén & 10.2 & 8.8 & 1.7 & 16.2 & 12.4 & 12.5 & 27.9 & 1.78 & 0.87 & 7.5 & 0.09 & -0.36 & 0.02 \\
\hline El Papiol & 5.3 & 0.3 & 0.2 & 1.6 & 1.4 & 3.7 & 2.9 & 0.40 & 0.13 & 7.2 & -1.14 & -2.76 & -1.36 \\
\hline
\end{tabular}
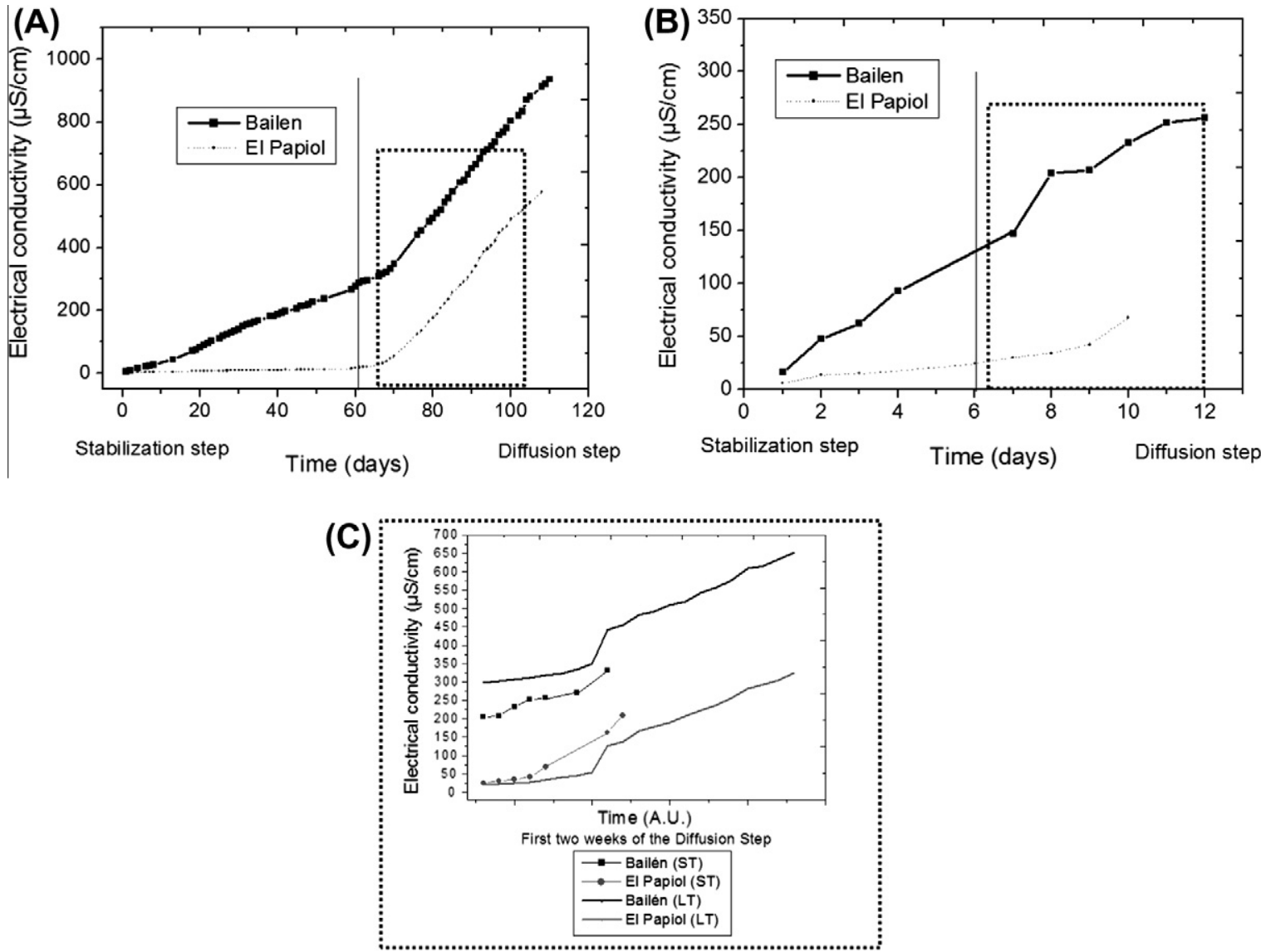

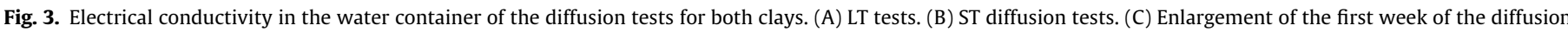
step for both ST and LT tests.

Table 5

Sulfate and chloride concentrations in the water container after LT tests (mol/L). Sulfate and chloride concentration measured in 1:20 aqueous extracts of the original clays $\left(\mathrm{mol} / \mathrm{kg}_{\mathrm{w}}\right)$

\begin{tabular}{llll}
\hline & & $\mathrm{SO}_{4}^{2-}$ & $\mathrm{Cl}^{-}$ \\
\hline Water container (ST) & Bailén & $1.8 \times 10^{-3}$ & $3.6 \times 10^{-4}$ \\
& El Papiol & $1.2 \times 10^{-4}$ & $8.0 \times 10^{-4}$ \\
Water container (LT) & Bailén & $1.4 \times 10^{-2}$ & $2.5 \times 10^{-2}$ \\
& El Papiol & $2.4 \times 10^{-4}$ & $2.9 \times 10^{-2}$ \\
Aqueous extracts & Bailén & 2.65 & $3.6 \times 10^{-2}$ \\
& El Papiol & $1.4 \times 10^{-2}$ & $2.3 \times 10^{-2}$ \\
\hline
\end{tabular}

extraction. For this reason, these data are not representative of the porewater chemistry when aqueous extracts are used instead of squeezing data.

\subsection{Boundary solutions}

Two boundary solutions have been used in the model (Fig. 2), distilled water and synthetic leachate. First, the distilled water container was simulated as water with very low solute concentrations (lower than $1 \times 10^{-6} \mathrm{~mol} / \mathrm{kg}_{\mathrm{w}}$ ). Second, the synthetic leachate has a comparable chemical composition to the leachate obtained from El Garraf landfill (Barcelona). The leachate from El Garraf landfill is a leachate from the methanogenic phase of the organic matter degradation in landfill areas (Cuevas et al., 2009). This leachate is characterized by high $\mathrm{pH}$ (around 8), a high content of $\mathrm{NH}_{4}^{+}$salts and low concentration of organic anions (Table 2).

\section{Results and discussion}

\subsection{Solute diffusion and $p H$}

The monitoring of salt concentration in the water container by means of Electrical conductivity (EC) shows a significant increase of this parameter shortly after the beginning of the second step (leachate diffusion). In both laboratory tests, values of EC are higher in Bailén clay than in El Papiol clay due to the fact that initial concentrations of solutes are higher in Bailén than in El Papiol pore waters. 

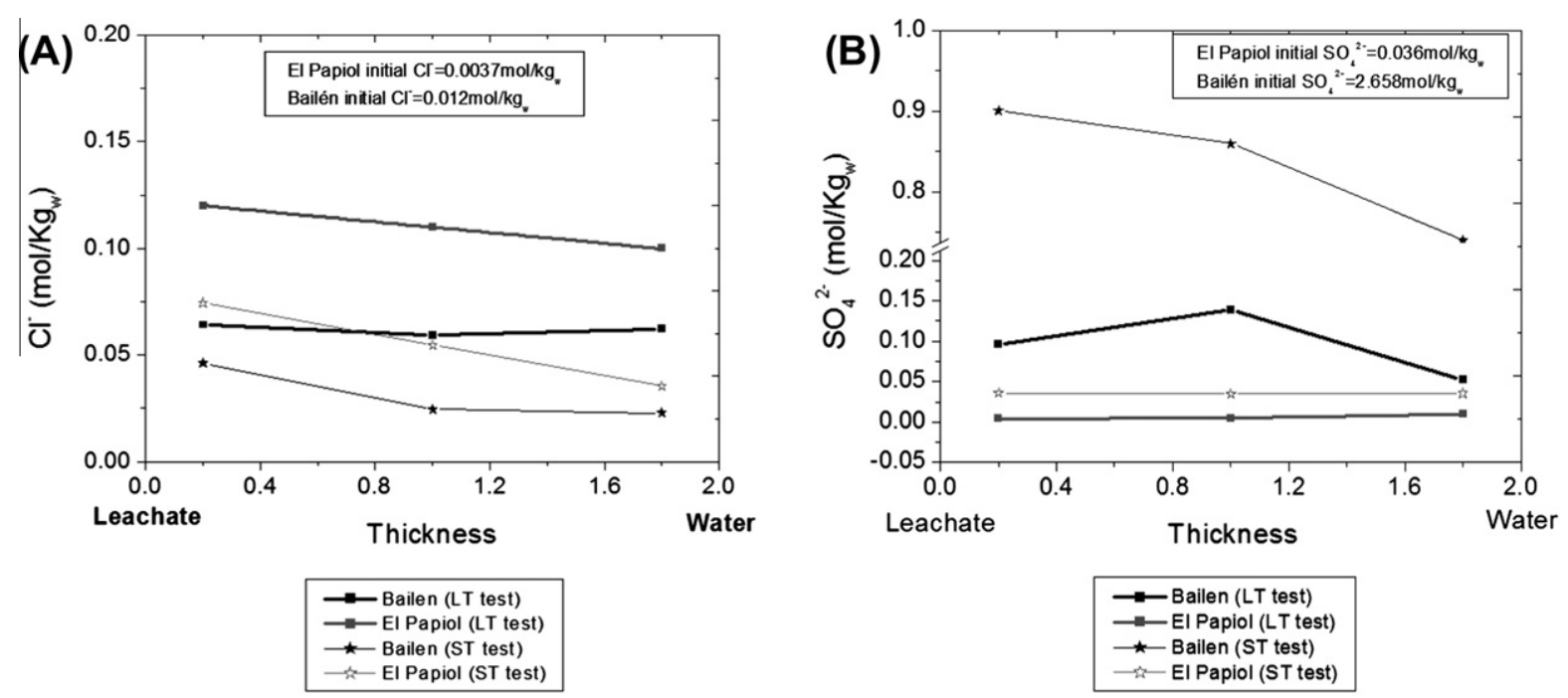

Fig. 4. Chloride and $\mathrm{SO}_{4}^{2-}$ soluble content in the samples after diffusion tests. (A) $\mathrm{Cl}^{-}$data, (B) $\mathrm{SO}_{4}^{2-}$ data.

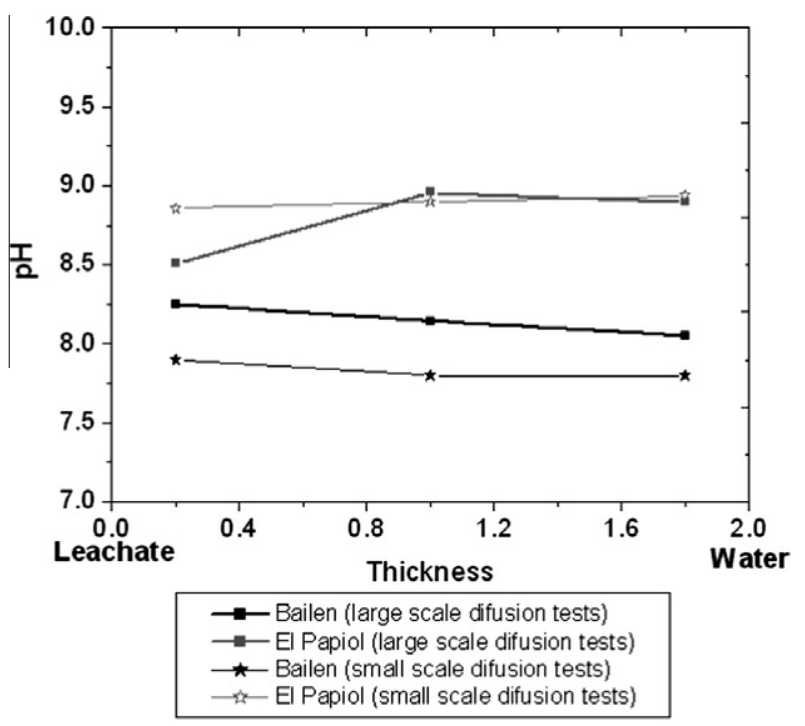

Fig. 5. $\mathrm{pH}$ values in the aqueous extract of the performed samples after diffusion tests.

A constant increase of EC was shown in the water container of the ST tests for both clays. However, the slope of the EC in LT tests was higher in the diffusion step than in the stabilization step, due to the arrival of the solute diffusion from the leachate. The increase of the slope of EC values was not constant during the whole leachate diffusion step. For approximately 5 days the increase was smaller than during the rest of the experiment (Fig. 3).

Sulfate concentrations in the water container at the end of the LT experiments were higher in Bailén than in El Papiol, in accordance with the initial $\mathrm{SO}_{4}^{2-}$ concentration measured in the 1:20 aqueous extracts of the original clays. However, $\mathrm{Cl}$ concentrations are quite similar for both clays (Table 5 ). There are differences between $\mathrm{SO}_{4}^{2-}$ concentration of the initial clay obtained by aqueous extracts (Table 5) and the $\mathrm{SO}_{4}^{2-}$ concentration obtained by squeezing (Table 4) due to the fact that sulfates are dissolved during the aqueous extract but not during the squeezing process.

Chloride concentration measured in the clay subsamples showed smaller values in ST tests than in the LT tests (Fig. 4A). In LT tests, the amount of $\mathrm{Cl}$ is constant in all samples. However, in ST tests, higher amounts of $\mathrm{Cl}$ were found in the solid subsample $\mathrm{S} 1$ than in S3. The $\mathrm{SO}_{4}^{2-}$ concentration showed the opposite trend compared to the $\mathrm{Cl}$ concentration. Sulfate concentration is significantly higher in the ST test than in the LT test (Fig. 4B). The reason for this can be related to both $\mathrm{SO}_{4}^{2-}$ diffusion to the reservoirs and with $\mathrm{SO}_{4}$-reduction processes. Sulfate-reducing bacteria take $\mathrm{SO}_{4}^{2-}$ from the porewater in order to degrade organic material (acetate) (Owen and Manning, 1996). Because Eh was not measured, the contribution of these two processes was evaluated later in the modeling of the experiments. The high concentration of $\mathrm{SO}_{4}^{2-}$ in Bailén clay is caused by the dissolution of gypsum in the aqueous extraction method.

While diffusion of $\mathrm{Cl}^{-}$is expected for Bailén clay, $\mathrm{SO}_{4}^{2-}$ will diffuse to both leachate and water container. In contrast, El Papiol is a clay material with a small concentration of solutes in the

Table 6

Mineralogical composition (\%) and specific surface area by BET $\mathrm{N}_{2}$ adsorption method $\left(\mathrm{m}^{2} / \mathrm{g}\right)$ of both clays used after diffusion tests.

\begin{tabular}{|c|c|c|c|c|c|c|c|c|c|}
\hline Clays & & $\mathrm{T}$ & Qtz & $\mathrm{Pl}$ & Kfs & Cal & Dol & Others & BET \\
\hline \multirow[t]{4}{*}{ ST } & Bailén S1 & 45 & 33 & $<1$ & $<1$ & 14 & 5 & Py: $<1$ & $25 \pm 2$ \\
\hline & Bailén S3 & 52 & 28 & $<1$ & $<1$ & 12 & 5 & Py: <1 & $30 \pm 1$ \\
\hline & Papiol_S1 & 65 & 23 & 1 & 1 & 6 & 2 & Hem: 2 & $22 \pm 1$ \\
\hline & Papiol_S3 & 56 & 31 & 1 & 1 & 7 & 2 & Hem: 2 & $20 \pm 1$ \\
\hline \multirow[t]{4}{*}{ LT } & Bailén_S1 & 48 & 30 & $<1$ & $<1$ & 16 & 3 & Py: $<1$ & $29 \pm 1$ \\
\hline & Bailén_S3 & 53 & 27 & $<1$ & $<1$ & 13 & 4 & Py: 1 & $30 \pm 1$ \\
\hline & Papiol_S1 & 54 & 32 & 2 & 1 & 8 & $<1$ & Hem: 2 & $18 \pm 0.5$ \\
\hline & Papiol_S3 & 57 & 26 & 2 & 3 & 7 & 2 & Hem: 1 & $19 \pm 0.5$ \\
\hline
\end{tabular}

T: total sheet-silicate content; Qtz: quartz, Pl: plagioclase; Kfs: K-feldspar; Cal: calcite; Dol: dolomite; Hem: hematite, Py: Pyrite. 
porewater where $\mathrm{NaCl}$ and sulfates are the dominant solutes (Table 4). Hence the diffusion of ions from the leachate will be the main process to be observed.

After the diffusion tests, $\mathrm{pH}$ values in aqueous extracts were between 8 and 9 for both ST and LT experiments (Fig. 5). The increase in $\mathrm{pH}$ induces the subsequent precipitation of calcite (Appelo, 1994).

The diffusion coefficients $\left(D_{e}\right)$ were fitted to the $\mathrm{Cl}^{-}$distribution in porewater at the end of the experiment, and it was assumed to be equal for all the aqueous species. The selection of this anion is because it was not present in significant concentrations in the initial clay porewater (Table 5 ), and because it is a conservative anion and diffusion is the only process which modified its composition in the clay porewater (Rowe, 1989). El Papiol clay was modeled with a unique diffusion coefficient $\left(D_{e}=2 \times 10^{-10} \mathrm{~m}^{2} / \mathrm{s}\right)$. Bailén material, however, needed two diffusion coefficients $\left(D_{e}=9 \times\right.$ $10^{-11} \mathrm{~m}^{2} / \mathrm{s}$ in the water-clay half and $D_{e}=1.5 \times 10^{-11} \mathrm{~m}^{2} / \mathrm{s}$ in the leachate-clay half). This fact was initially attributed to a significant calcite precipitation in Bailén clay after the test in the clay-leachate contact (Table 6) as far as calcite precipitation decreases the porosity of the clay material (VanGulck and Rowe, 2004a) resulting in a decrease in the apparent diffusion coefficient of the solutes. Considering the precipitation of calcite, by increasing its content by $5 \%$ the porosity should decrease from 0.41 to $0.38 \quad(<10 \%$ variation), which cannot explain the variation of the diffusion coefficients (almost one order of magnitude) calculated. It is clear that most of the porosity change was caused by either change in the interlayer volume space or the effective volume available for the diffusion of anions (i.e., Van Loon et al., 2007). There was no mechanistic treatment of the behavior of the interparticle spaces or different types of porosity in the model. This kind of treatment will be necessary for a more detailed understanding of the transport phenomena in compacted clays. In spite of this, the data obtained in the simulation matched the analytical data for both clays (Fig. 6). The different approach needed for the two clays is also in agreement with the changes in specific surface in the ST tests for the Bailén clay. Similar diffusion coefficients for $\mathrm{Cl}^{-}$were obtained in diffusion laboratory experiments performed with natural clay with carbonates by Barone et al., (1990).

\subsection{Cation exchange}

Cation exchange capacity (CEC) is $13.2 \pm 1 \mathrm{cmol}(+) / \mathrm{kg}$ for Bailen clay and $15.3 \pm 0.9 \mathrm{cmol}(+) / \mathrm{kg}$ for El Papiol clay (Table 7). CEC did not change during the diffusion test.

Due to the fact that the analytical method used for the exchangeable cation extraction dissolved carbonates and sulfates, the $\mathrm{Ca}^{2+}$ and $\mathrm{Mg}^{2+}$ concentrations are overestimated (Dohrmann, 2006; Dohrmann and Kaufhold, 2010). To correct the error, it is assumed that Ca concentration could be recalculated, following the next equation:

$$
\mathrm{Ca}^{2+}=\mathrm{CEC}-\left(\mathrm{Na}^{+}+\mathrm{K}^{+}+\mathrm{NH}_{4}^{+}+\mathrm{Mg}^{2+}\right)
$$

This is consistent with the slow kinetics assumed for the dissolution of dolomite (Chou et al., 1989). However, in the LT experiments, both $\mathrm{Mg}^{2+}$ and $\mathrm{Ca}^{2+}$ concentrations should become overestimated. In this case it has been assumed that equilibrium
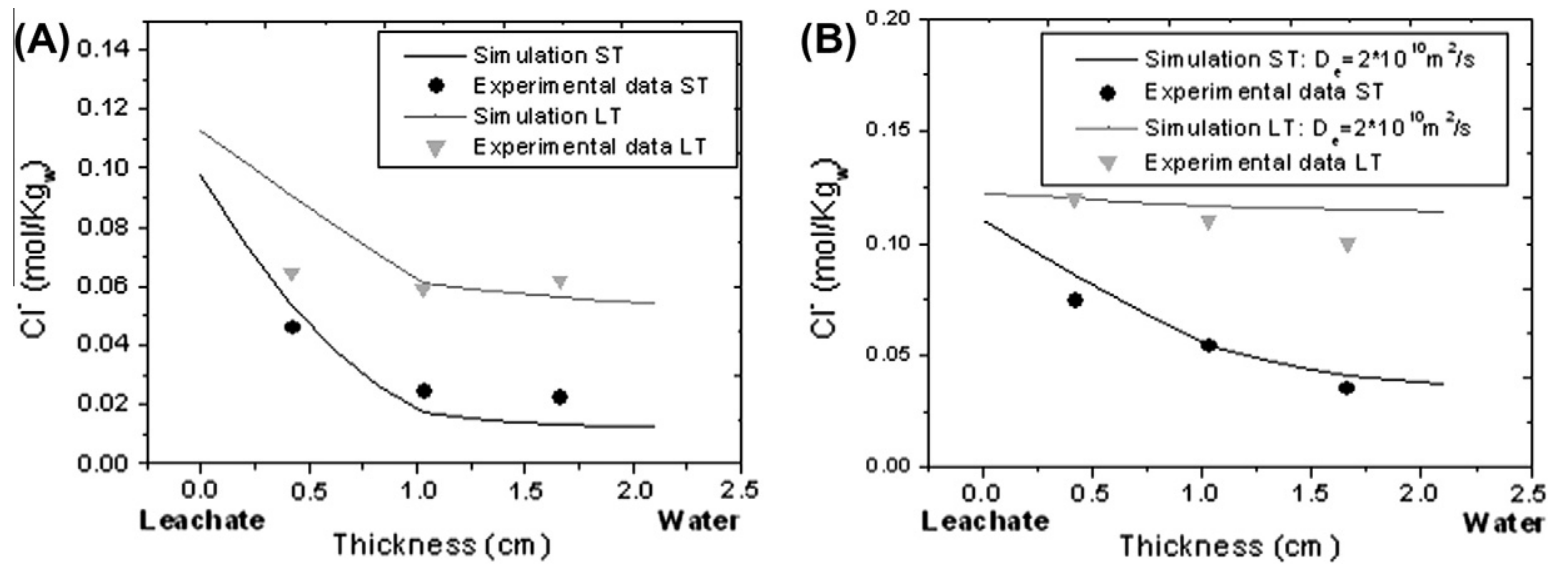

Fig. 6. Experimental $\mathrm{Cl}^{-}$data and simulation $\mathrm{Cl}^{-}$data of the ST and LT experiments for both clays. (A) Bailén data. (B) El Papiol data.

Table 7

Cation exchange composition of the original samples, ST experiments and LT experiments $(\mathrm{cmol}(+) / \mathrm{kg})$.

\begin{tabular}{|c|c|c|c|c|c|c|}
\hline & & $\mathrm{NaX}$ & $\mathrm{KX}$ & $\mathrm{NH}_{4} \mathrm{X}$ & $\mathrm{CaX}_{2}$ & $\operatorname{MgX}_{2}$ \\
\hline \multirow[t]{2}{*}{ Original clay } & Bailén & 0.40 & 0.9 & n.d. & 8.0 & 4.2 \\
\hline & El Papiol & 0.9 & 0.9 & n.d. & 7.7 & 5.8 \\
\hline \multirow[t]{6}{*}{ ST tests } & Bailén_S1 & 1.3 & 0.9 & 2.5 & 5.4 & 3.2 \\
\hline & Bailén_S2 & 0.9 & 0.9 & 1.6 & 6.2 & 3.7 \\
\hline & Bailén_S3 & 1.1 & 1.0 & 1.2 & 5.9 & 4.0 \\
\hline & El Papiol_S1 & 1.5 & 0.8 & 2.6 & 6.3 & 4.1 \\
\hline & El Papiol_S2 & 1.1 & 0.8 & 0.5 & 8.9 & 4.4 \\
\hline & El Papiol_S3 & 0.8 & 0.9 & 0.2 & 9.4 & 4.4 \\
\hline \multirow[t]{6}{*}{ LT tests } & Bailén_S1 & 2.7 & 0.4 & 6.2 & 3.0 & 1.0 \\
\hline & Bailén_S2 & 3.1 & 0.3 & 5.9 & 3.0 & 1.0 \\
\hline & Bailén_S3 & 2.8 & 0.3 & 6.1 & 3.0 & 1.0 \\
\hline & El Papiol_S1 & 3.0 & 0.2 & 10.6 & 1.0 & 0.5 \\
\hline & El Papiol_S2 & 3.2 & 0.2 & 9.4 & 1.6 & 0.8 \\
\hline & El Papiol_S3 & 2.9 & 0.2 & 9.8 & 1.6 & 0.8 \\
\hline
\end{tabular}

n.d.: not detected. 
(A)
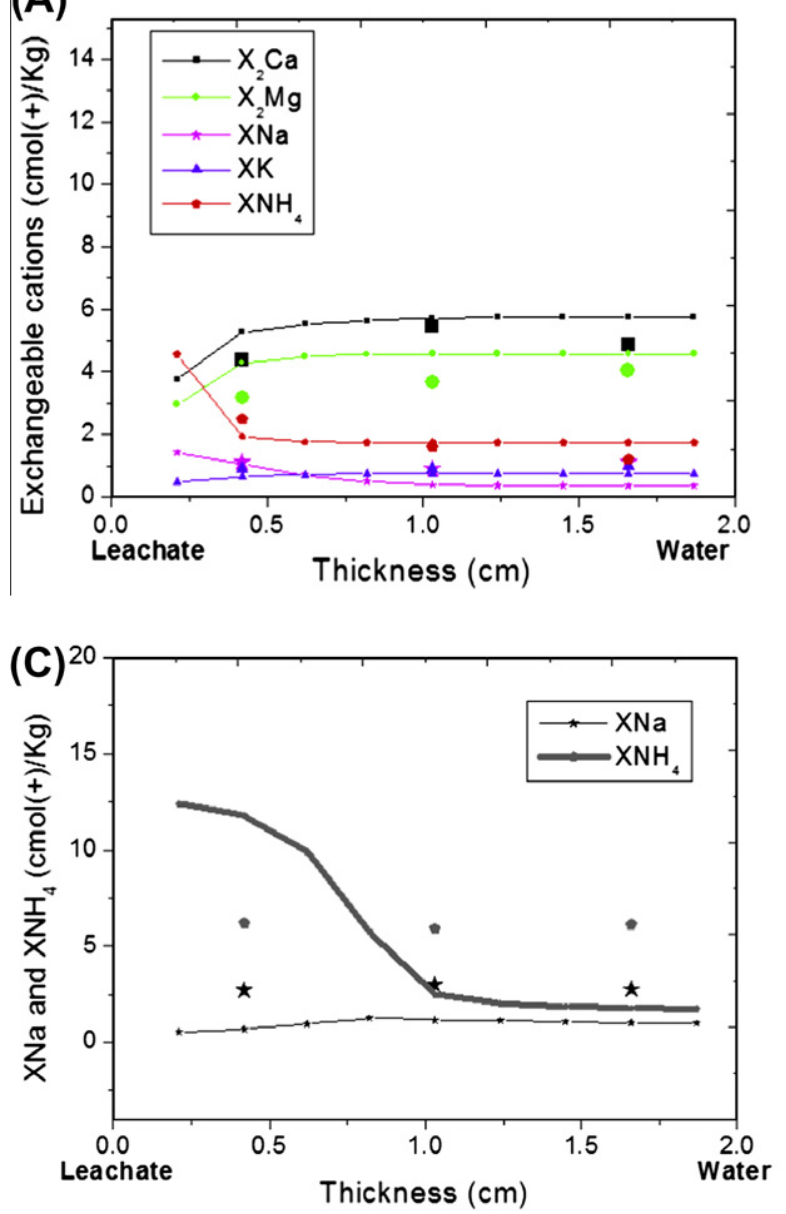

(B)
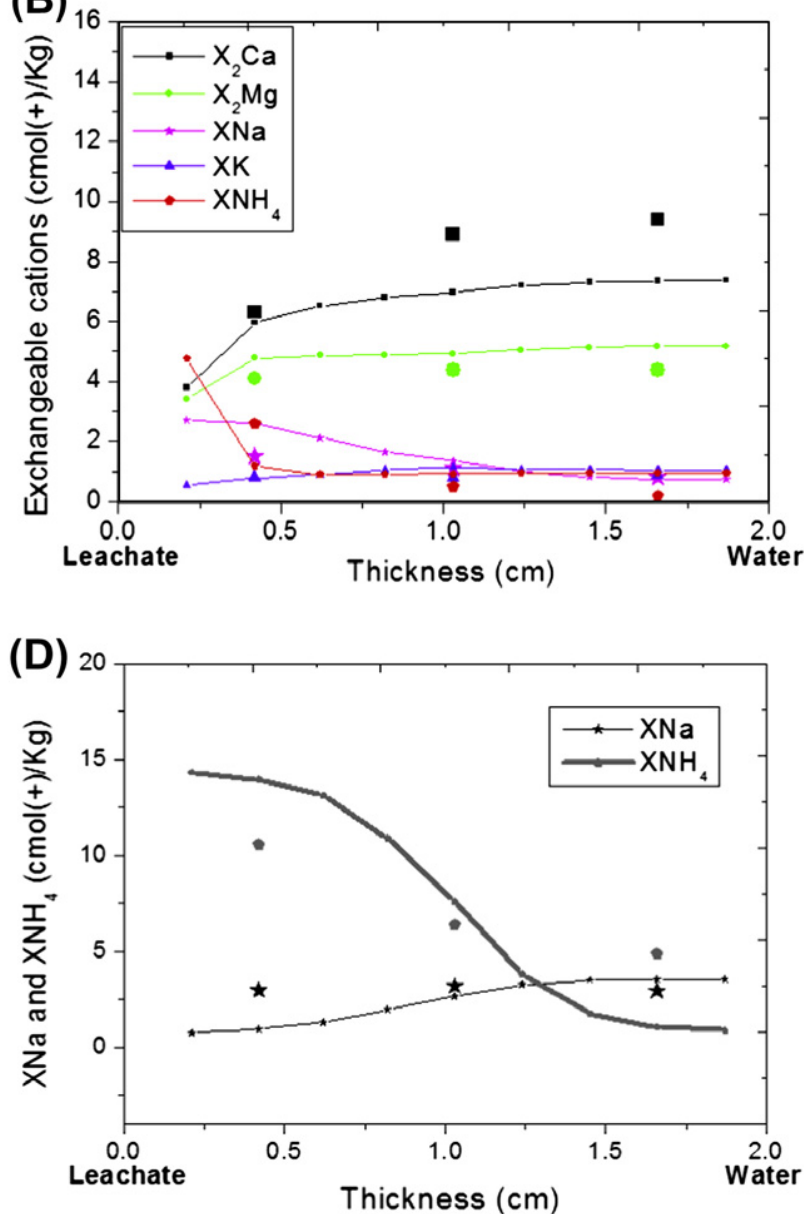

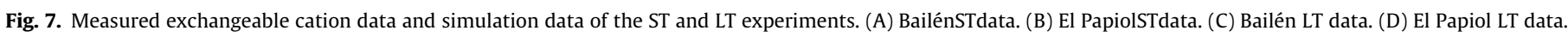

is achieved and the measured $\mathrm{Mg} / \mathrm{Ca}$ ratio is maintained in the exchange complex. Unfortunately it was not possible to perform the squeezing method to determine porewater chemistry in both ST and LT samples (see methods section). Exchangeable $\mathrm{NH}_{4}^{+}$in the subsamples clearly shows a significant gradient between $\mathrm{S} 1$ and S3 for the ST tests, the concentration of $\mathrm{NH}_{4}^{+}$is higher in the leachate-clay interface than in the opposite area. This was not observed in samples from the LT tests. In these tests the clay porewater reached a steady state condition for the different composition of the water and the leachate containers. Exchangeable $\mathrm{Na}^{+}$ values show similar distribution patterns as observed with exchangeable $\mathrm{NH}_{4}^{+}$between $\mathrm{S} 1$ and S3 for LT and ST experiments (Table 7). As a consequence $\mathrm{NH}_{4}^{+}$and $\mathrm{Na}^{+}$prevailed in the exchange clay complex of the clay in LT experiments.

The $\mathrm{Ca}^{2+}, \mathrm{Mg}^{2+}$ and $\mathrm{K}^{+}$concentrations for both clays after diffusion tests decreased compared with the initial cation exchange concentrations (Table 7). Desorption of these cations occurs during the sorption of $\mathrm{Na}^{+}$and $\mathrm{NH}_{4}^{+}$from the leachate. This process favored calcite precipitation at the leachate-clay contact due to an increase of $\mathrm{Ca}^{2+}$ in the porewater. The precipitation of calcite is consistent with the SI obtained with PHREEQC for the initial porewater from both clays (Table 4).The sorption of $\mathrm{NH}_{4}^{+}$is more important in El Papiol clay than in Bailén material after the LT test which could be explained by the relatively low reactivity of the coarse grained carbonates in El Papiol clay.

The model calculations fit the trend of the measured exchangeable cations in the ST tests. The cation displaced is preferentially $\mathrm{Ca}^{2+}$, which is exchanged with $\mathrm{Na}^{+}$and $\mathrm{NH}_{4}^{+}$from the leachate.
However, this displacement is not equal in both clays; there is a relationship between the chemical composition of the cation exchange complex and the gypsum content. As expected, the clay from El Papiol shows that the exchange of $\mathrm{Ca}^{2+}$ for $\mathrm{Na}^{+}$and $\mathrm{NH}_{4}^{+}$ from the leachate is more prominent than in the Bailén, whereby dissolution of gypsum supplies additional $\mathrm{Ca}^{2+}$ to the pore water (Fig. 7A and B). In LT experiments, measured $\mathrm{NH}_{4}^{+}$and $\mathrm{Na}^{+}$concentrations fit the trend of these cation concentrations of the model. The highest concentrations of $\mathrm{NH}_{4}^{+}$are obtained in the leachate area for both clays due to the incorporation of this cation in the exchangeable complex and its high selectivity relative to $\mathrm{Na}^{+}$ (Fig. 7C and D). This trend is more pronounced in El Papiol clay.

\subsection{Mineralogy and surface area of clays}

No significant changes were found in the mineralogy of the clays (Table 6 ). The only exception was a minor dissolution of dolomite and precipitation of calcite in the contact area between clay and synthetic leachate (S1) in LT test. The precipitation of calcite and dissolution of dolomite is more significant in Bailén than in El Papiol due to the fact that the carbonate content in Bailén is higher than in El Papiol (Fig. 8). After the ST test, very small changes were determined: dolomite in the Bailén clay became altered, the $2.89 \AA$ dolomite peak is partially shifted to $2.92 \AA$. This indicates the formation of a $\mathrm{Ca}^{2+}$-rich dolomite (Zhang et al., 2010).

Observations using the optical microscope in the LT tests confirm the precipitation of calcite in the leachate-clay region. Small new crystals of calcite were found in the leachate-clay interface 

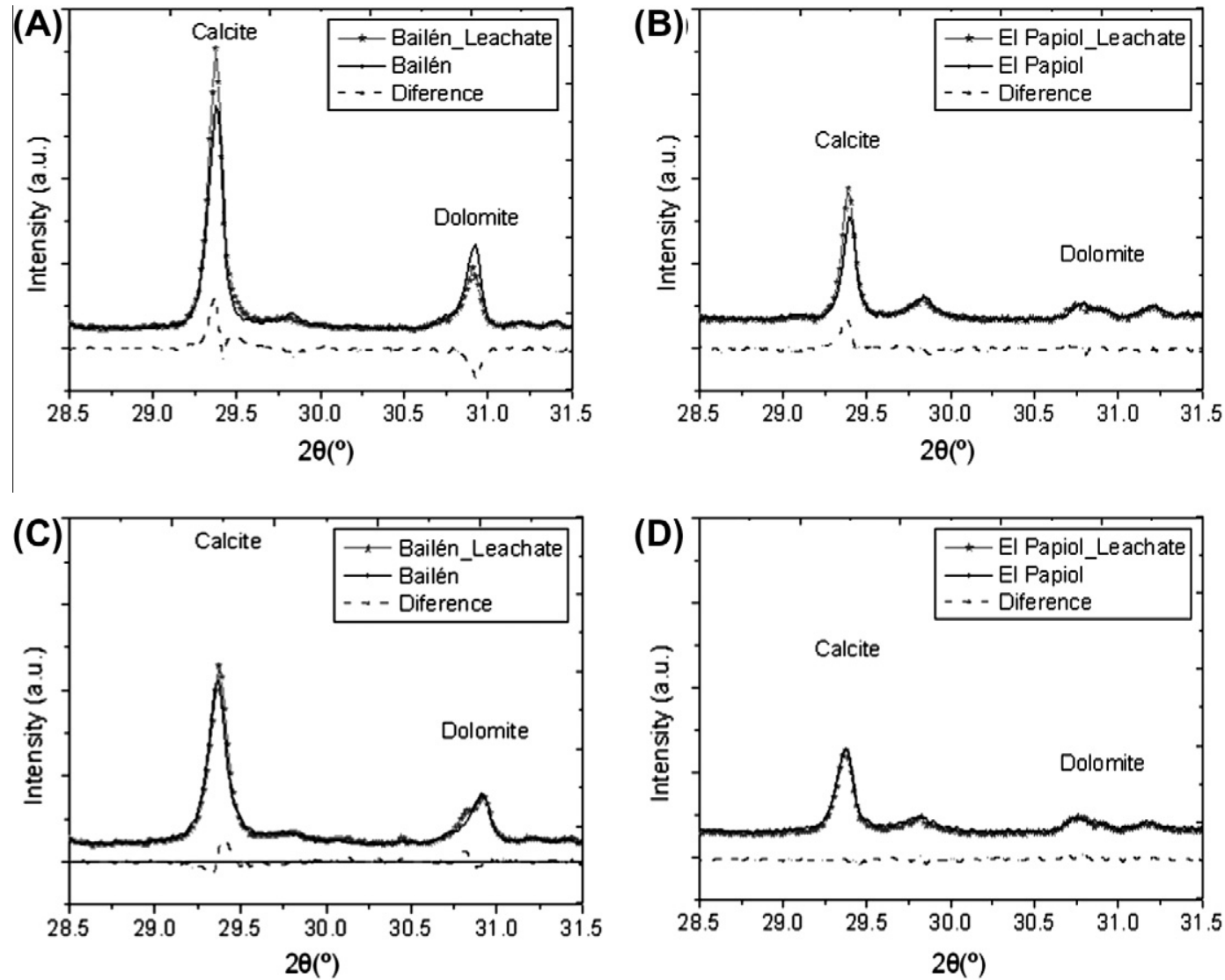

Fig. 8. Detail of carbonate random powder XRD patterns of Bailén and El Papiol clays after large (A and B) and small scale diffusion test (C and D).

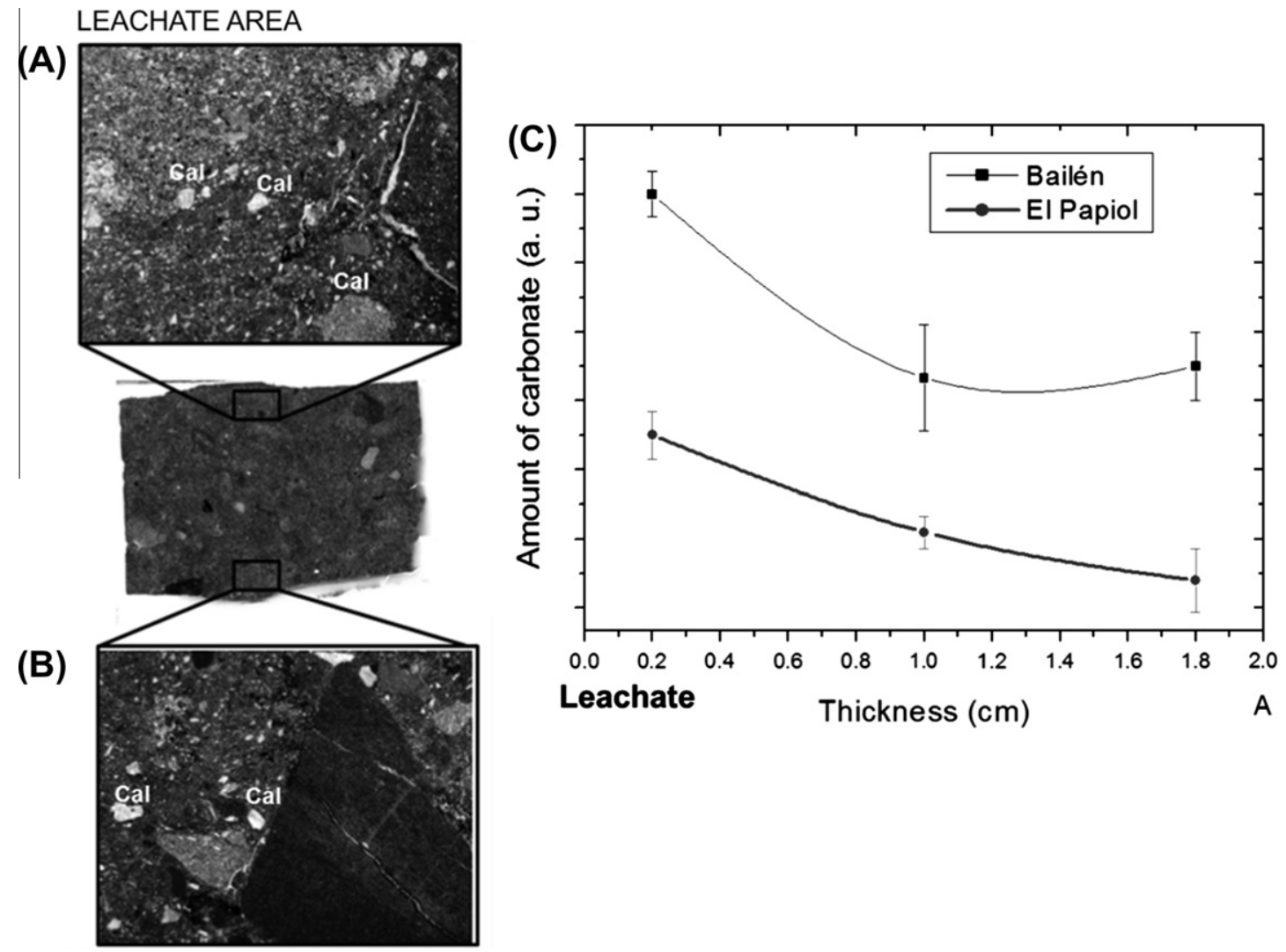

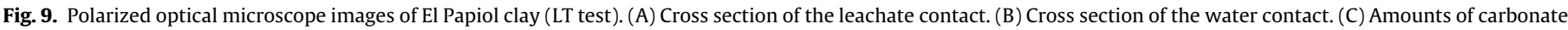
grains for Bailén and El Papiol clay cal: calcite grains. 


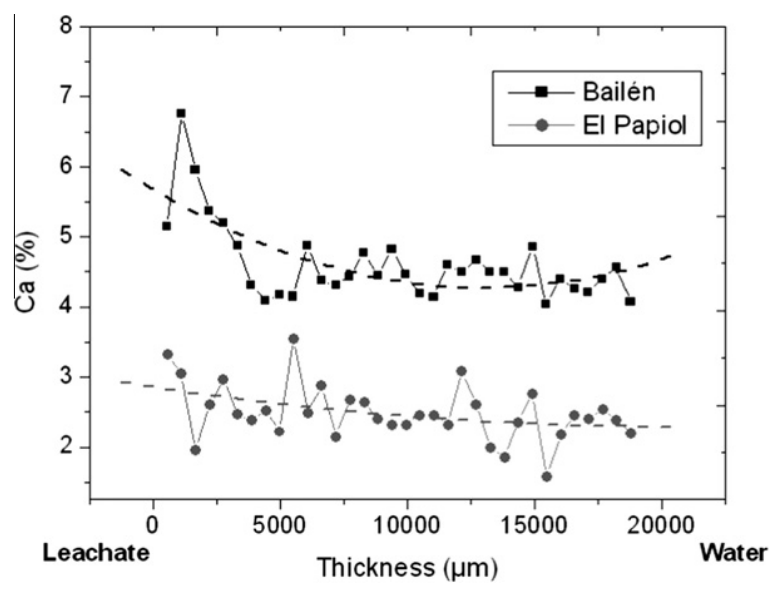

Fig. 10. Calcium distribution acrossBailén and El Papiol samples by SEM-EDX.

area (Fig. 9A), which is observed by a number of tiny birefringent crystals that are less visible at the water contact (Fig. 9B) zone than in the leachate area. In the case of Bailén, the effect is less evident because the size of the crystals $(0.1-0.4 \mathrm{~mm})$ is smaller than the crystal size of El Papiol (0.3-0.7 mm). Moreover, along transverse profiles of the thin sections, greater amounts of carbonate crystals are observed close to the leachate boundary especially in the Bailén clay (Fig. 9C). The SEM-EDX of element profiles also confirm an enrichment of $\mathrm{Ca}$ in the leachate-clay contact (Fig. 10). The increase of $\mathrm{Ca}$ is more pronounced in the case of Bailén than in $\mathrm{El}$ Papiol, which is consistent with the significant calcite precipitation in this clay observed by XRD and the study of thin sections.

Values of $\mathrm{N}_{2}$ BET specific surface of the initial clays are: Bailén, $29 \pm 1 \mathrm{~m}^{2} / \mathrm{g}$ and El Papiol, $19 \pm 0.5 \mathrm{~m}^{2} / \mathrm{g}$. The external specific surface of platy clay particles is related to the degree of coherent stacking of quasicrystals (Metz et al., 2005). The El Papiol clay shows a very small variation of the initial external specific surface. The Bailén clay shows a significant decrease of external specific surface, from 29 to $25 \mathrm{~m}^{2} / \mathrm{s}$ in the ST experiments at the section in contact with water. The difference is not significant in the LT experiments. The perturbation of this property could be linked to an initial rearrangement of particles due to the clay expansion at the dilute water side. This expansion is favored by the increase of pore space in the high salinity leachate side and the shrinking of the Double Diffuse Layer between clay platelets. This pore space is eventually reduced by the swelling pressure generated by the smectite component on the dilute water side (Arasan et al., 2010) and finally stabilized as porewater salinity is homogenized in the LT experiments.

Changes in the mineralogical composition of the studied clays are also calculated with the models; precipitation of calcite is obtained for both clays in the leachate area after ST and LT diffusion tests (Fig. 11) in accordance with the mineralogical results
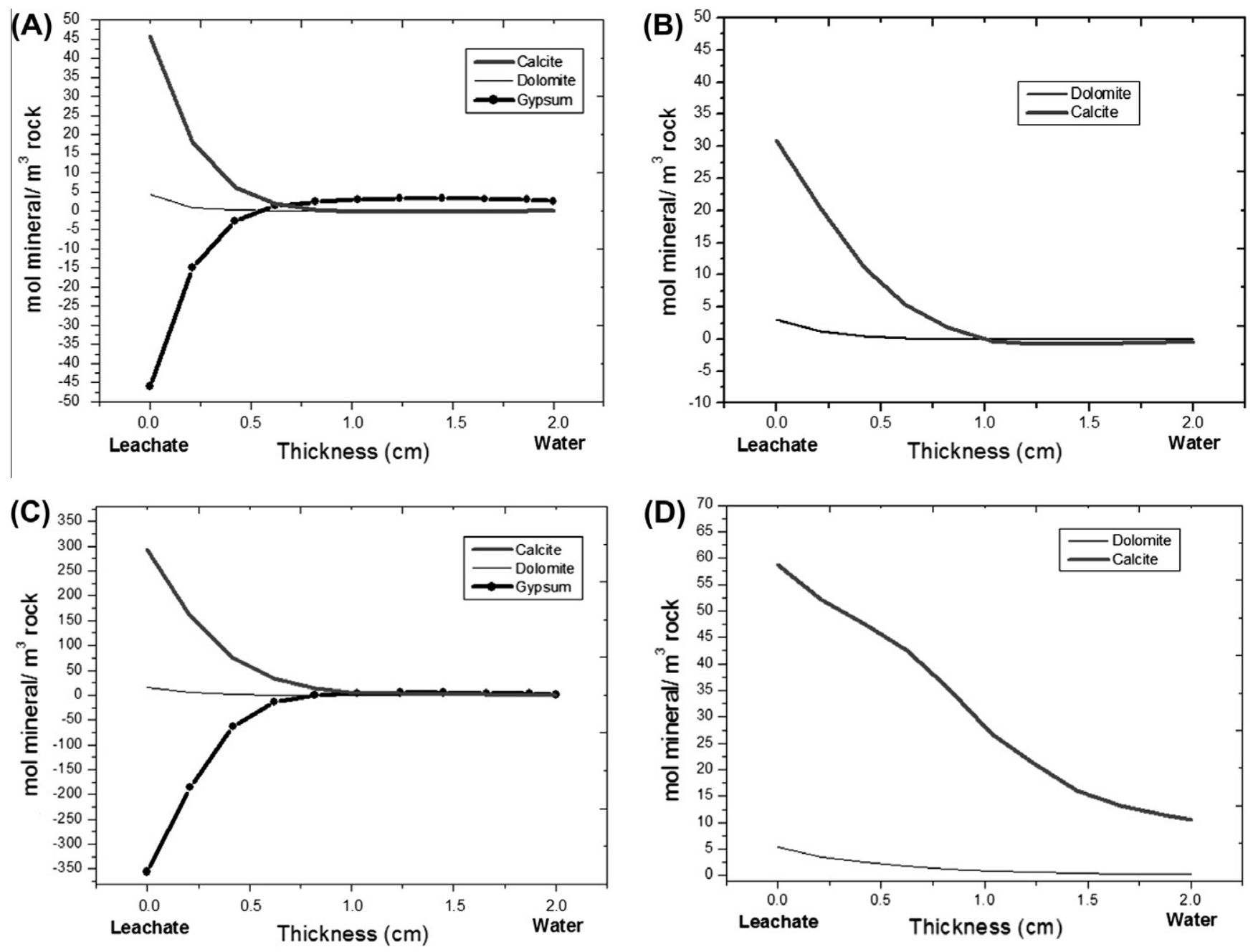

Fig. 11. Model mineralogical data of the ST and LT experiment. (A) BailénSTdata. (B) El PapiolSTdata. (C) Bailén LT data. (D) El Papiol LT data. 

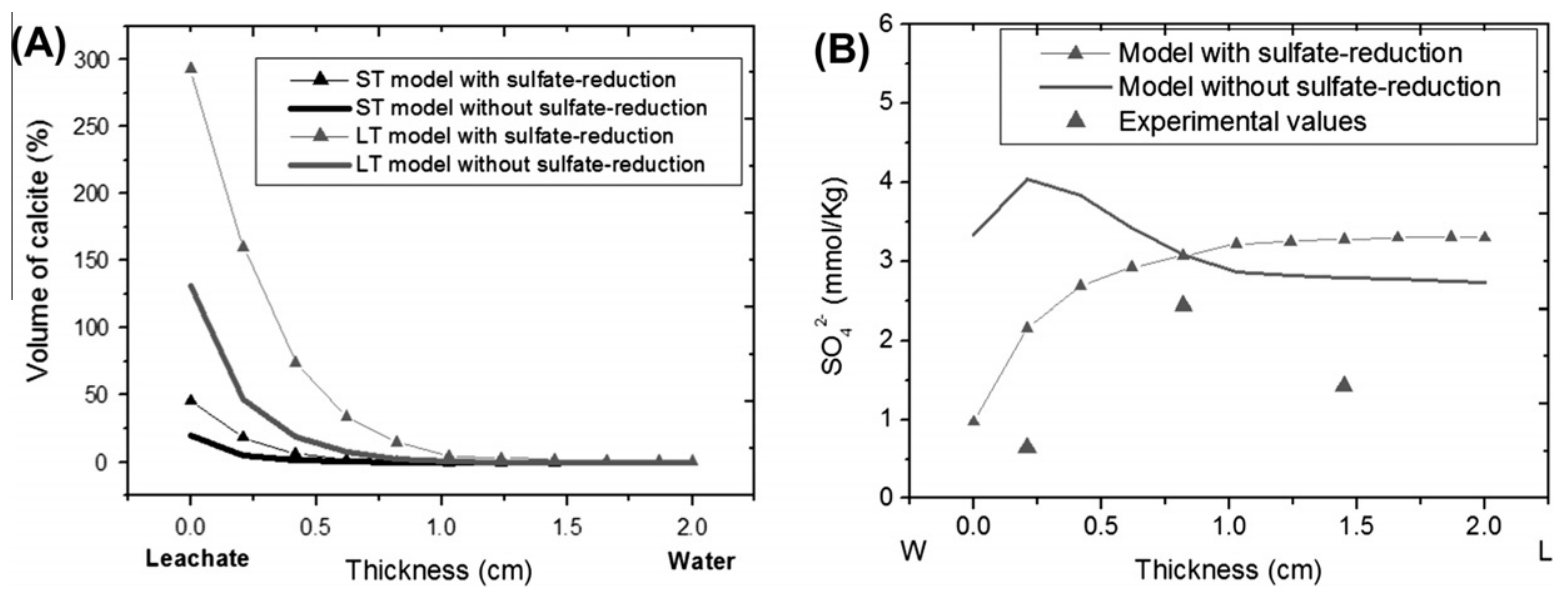

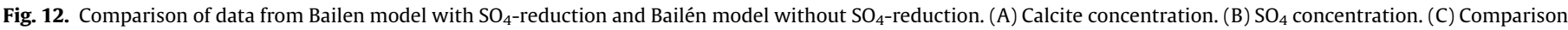
of analytical $\mathrm{SO}_{4}$ concentration with total $\mathrm{SO}_{4}$ concentration in the models $(\mathrm{mol} / \mathrm{kg}$ ).

obtained by XRD (Table 6) and with the decrease of porosity suggested by the $\mathrm{Cl}^{-}$diffusion modeling. In the Bailén clay, $\mathrm{SO}_{4}-$ reduction produces dissolution of gypsum. The incorporation of $\mathrm{SO}_{4}$-reduction in the Bailén model involves a decrease of the $\mathrm{SO}_{4}^{2-}$ concentration and a significant precipitation of calcite due to the increase in the $\mathrm{HCO}_{3}^{-}$concentration in the final porewater. In agreement with the model, the amount of calcite precipitated in the S1 slice of the LT tests ( $7 \mathrm{~mm}$ thickness) is $0.3 \%$, or $1 \%$ if $\mathrm{SO}_{4}$-reduction is considered (Fig. $12 \mathrm{~A}$ ). The experimentally determined increase of calcite in this section is about 3-5\%, which is more consistent with $\mathrm{SO}_{4}$-reduction processes. Then, the process should be more developed in the experiment for the model prediction. The existence of $\mathrm{SO}_{4}$-reduction is also consistent with the significant decrease of total $\mathrm{SO}_{4}$ (gypsum + porewater $\mathrm{SO}_{4}^{2-}$ ) over the long term (LT; Fig 4). The total $\mathrm{SO}_{4}$ in the LT experiment is about $1 / 10$ of the original value, which is consistent with the model prediction when total $\mathrm{SO}_{4}$ is calculated according to the remaining total $\mathrm{SO}_{4}$ in the LT related to the mass of solid (Fig. $12 \mathrm{~B}$ ).The model without $\mathrm{SO}_{4}$-reduction predicts a decrease of $1 / 4$ by pure diffusion.

\section{Conclusions}

Natural clay materials contain small amounts of soluble accessory minerals such as calcite, dolomite and gypsum, which condition the transport and reaction properties of clay barriers used for landfill leachate attenuation.

Landfill leachates usually contain high concentrations of $\mathrm{Cl}^{-}$, $\mathrm{NH}_{4}^{+}$and soluble low molecular weight organic acids. The diffusion of $\mathrm{Cl}^{-}$has been used in this work to determine the overall fluid transport behavior in compacted clays. Apparent diffusion coefficients for $\mathrm{Cl}^{-}$transport have been calculated for both clays. El Papiol clay with a small initial concentration of soluble salts shows a larger diffusion coefficient $\left(D_{e}=2 \times 10^{-10} \mathrm{~m}^{2} / \mathrm{s}\right)$ than Bailén clay $\left(D_{e}=9 \times 10^{-11}\right.$ and $\left.1.5 \times 10^{-11} \mathrm{~m}^{2} / \mathrm{s}\right)$. Variation for Bailén clay is related to a decrease in porosity in the leachate-clay contact, mostly attributed to interparticle volume decrease near the leachate, rather than a significant precipitation of calcite. This precipitation is driven by $\mathrm{NH}_{4}$ and $\mathrm{Na}$ exchange with the initial cations of the exchange complex (mainly $\mathrm{Ca}$ ). This process produces an increase of $\mathrm{Ca}$ in the porewater of the clays and supersaturation of calcite in the porewater.

Sulfate reduction coupled with acetate oxidation has been proven to be relevant in samples with a significant concentration of $\mathrm{SO}_{4}^{2-}$ (Bailén). This process also promotes significant precipitation of carbonates (mainly calcite) and produces a decrease of $\mathrm{SO}_{4}^{2-}$ in the porewater. These reactions potentially ensure a buffer capacity that provides a high enough $\mathrm{pH}$ (8-9) to offer a suitable long-term retention of metal ions precipitated as hydr/oxides or carbonates (Mostbauer, 2003). Regadío et al. (2012) and Regadío (2012) have determined, in clay substrata studied below old landfills, a lack of migration at depth of $\mathrm{Cu}, \mathrm{Cr}, \mathrm{Cd}$ and $\mathrm{Zn}$, which content were positively correlated with the increase of calcite. Calcite was found concentrated within shallow depths in the clay materials held in contact with leachate and waste. However, although the presence of these accessory minerals would add valuable performance functions to clay barriers, it is obvious that excessive precipitation of calcite or high amounts of $\mathrm{SO}_{4}^{2-}$ will compromise the surface retention properties of the barrier materials (pore clogging), or will promote undesirable sulfide gas generation. Therefore, suitable limits for these reactive accessory minerals should be examined in future research.

\section{References}

Appelo, C.A.J. 1994. Cation and proton exchange, $\mathrm{pH}$ variations, and carbonate reactions in a freshening aquifer. Water Resour. Res. 30, 2793-2805.

Appelo, C.A.J., Postma, D., 2005. Geochemistry, Groundwater and Pollution. Amsterdam, Balkema.

Appelo, C.A.J., Van Loon, L.R., Wersin, P., 2010. Multicomponent diffusion of a suite of tracers ( $\mathrm{HTO}, \mathrm{Cl}, \mathrm{Br}, \mathrm{I}, \mathrm{Na}, \mathrm{Sr}, \mathrm{Cs}$ ) in a single sample of Opalinus Clay. Geochim. Cosmochim. Acta 74, 1201-1219.

Arasan, S., KaganAkbulut, R., Yetimoglu, T., Yilmaz, G., 2010. Swelling pressure of compacted clay liners contaminated with inorganic salt solutions. Environ. Eng. Geosci. 16, 401-409.

Barone, F.S., Yanful, E.K., Quigley, R.M., Rowe, R.K., 1990. Laboratory determination of chloride diffusion coefficient in an intact shale. Can. Geotech. J. 27, 177-184.

Birgersson, M., Karnland, O., 2009. Ion equilibrium between montmorillonite interlayer space and an external solution - consequences for diffusional transport. Geochim. Cosmochim. Acta 73, 1908-1923.

Bourg, I.C., Bourg, A.C.M., Sposito, G., 2003. Modeling diffusion and adsorption in compacted bentonite: a critical review. J. Contam. Hydrol. 61, 293-302.

Bradbury, M., Baeyens, B., 2000. A generalized sorption model for the concentration dependent uptake of caesium by argillaceous rocks. J. Contam. Hydrol. 42, 141163.

Bradbury, M., Baeyens, B., 2003. Porewater chemistry in compacted re-saturated MX-80 bentonite. J. Contam. Hydrol. 61, 329-338.

Chou, L., Garrels, R.M., Wollast, R., 1989. Comparative study of the kinetics and mechanisms of dissolution of carbonate minerals. Chem. Geol. 78, 269-282.

Christensen, T.H., Bjerg, P.L., Banwart, S.A., Jakobsen, R., Heron, G., Albrechtsen, H.J., 2000. Characterization of redox conditions in groundwater contaminant plumes. J. Contam. Hydrol. 45, 165-241.

Cobeña, J.C., Cuevas, J., Martín, M., Ramírez, S., Vigil de la Villa, R., Leguey, S., 1999 Estudio de la mineralogía y microestructura de una bentonita compactada. Efectos de calentamiento e hidratación. Boletín Soc. Geol. Miner. 22, 235-247.

Cuevas, J., Leguey, S., Garralón, A., Rodríguez Rastrero, M., Procopio, J.R., Sevilla, M.T., Sánchez Jiménez, N., Rodríguez Abad, R., Garrido, A., 2009. Behavior of kaolinite and illite-based clays as landfill barriers. Appl. Clay Sci. 42, 497-509.

Cuevas, J., Ruiz, A.I., de Soto, I.S., Sevilla, T., Procopio, J.R., da Silva, P., Gismera, M.J., Regadío, M., Sánchez Jiménez, N., Rodríguez Rastrero, M., Leguey, S., 2012. The 
performance of natural clay as a barrier to the diffusion of municipal solid waste landfill leachates. J. Environ. Manage. 95, S175-S181.

Cuevas, J., Villar, M.V., Fernández, A.M., Gómez, P., Martin, P.L., 1997. Pore waters extracted from compacted bentonite subjected to simultaneous beating and hydration. Appl. Geochem. 12, 473-481.

Dohrmann, R., 2006. Cation exchange capacity methodology III: correct exchangeable calcium determination of calcareous clays using a new silverthiourea method. Appl. Clay Sci. 34, 47-57.

Dohrmann, R., Kaufhold, S., 2010. Three new, quick CEC method for determinating the amounts of exchangeable calcium cations in calcareous clays. Clay Clay Miner. 57, 338-352.

Drever, L.L., 1998. The Geochemistry of Natural Waters. Prentice Hall, New Jersey.

Foged, N., Baumann, J., 1999. Clay membrane made of natural high plasticity clay: leachate migration due to advection and diffusion. Eng. Geol. 54, 129-137.

González, I., Galán, E., Miras, A., Aparicio, P., 1998. New uses for brick-making clays materials from the Bailén area (Southern Spain). Clay Miner. 33, 453-465.

Hervás, J., Martínez Santamaría, J.M., Ruiz, A.I., Regadío, M., de Soto, I., Rodríguez, M., Cuevas, J. 2010. Long term column experiments for testing the landfill leachate diffusion through $0.5 \mathrm{~m}$ thick compacted clay. In: Proc. 6th Internat. Congress Environmental Geotechnics. Tata McGraw Hill Education Private Limited. New Delhi, India.

Islam, J., Singhal, N., 2004. A laboratory study of landfill leachate transport in soils. Water Res. 38, 2035-2042.

Kang, J.B., Shackelford, C.D., 2010. Membrane behavior of compacted clay liners. J. Geotech. Geoenviron. Eng. 136, 1368-1383.

Komine, H., Ogata, N., 1996. Prediction for swelling characteristics of compacted bentonite. Can. Geotech. J. 33, 11-22.

Kraehenbuehl, F., Stoeckli, H.F., Brunner, F., Kahr, G., Muller-Vonmoos, M., 1987. Study of the water-benonite system by vapour adsorption, immersion calorimetry and X-ray techniques: I. Micropore volumes and internal surface areas, following Dubinińs theory. Clay Miner. 22, 1-9.

Malusis, M.M., Shackelford, C.D., Olsen, H.W., 2003. Flow and transport through clay membrane barriers. Eng. Geol. 70, 235-248.

Metz, V., Raanan, H., Pieper, H., Bosbach, D., Ganor, J., 2005. Towards the establishment of a reliable proxy for the reactive surface area of smectite. Geochim. Cosmochim. Acta 69, 2581-2591.

Molera, M., Eriksen, T., Jansson, M., 2003. Anion diffusion pathways in bentonite clay compacted to different dry densities. Appl. Clay Sci. 23, 69-76.

Montes-H, G., Fritz, B., Clement, A., Michau, N., 2005. Modelling of geochemical reactions and experimental cation exchange in MX80 bentonite. J. Environ. Manage. 77, 35-46.

Mostbauer, P., 2003. Criteria selection for landfills: do we need a limitation on 1162 inorganic total content. Waste Manage. (Oxford) 23, 547-554.

Owen, J.A., Manning, D.A.C., 1996. Silica in landfill leachates: implications for clay mineral stabilities. Appl. Geochem. 12, 267-280.

Parkhurst, D.L., Appelo, C.A.J., 1999. User's Guide to PHREEQC (Version 2) - A Computer Program for Speciation, Batch Reaction, One-Dimensional Transport, and Inverse Geochemical Calculations. US Geol. Surv. Water-Resour. Invest. Rep. 99-4259.

Pivato, A., Raga, R., 2006. Tests for the evaluation of ammonium attenuation in MSW landfill leachate by adsorption into bentonite in a landfill liner. Waste Manage. (Oxford) 26, 123-132.

Primo Martín, V., 2002. DRXWIN 2.2.56. <http://icmuv.uv.es/drxwin>

Pusch, R., 2006. Clays and nuclear waste management. In: Bergaya, F., Theng, B.K.G. Lagarly, G. (Eds.), Handbook of Clay Science. Elsevier, Oxford, pp. 703-716.

Regadío, M., 2012. Difusión de contaminantes en vertederos antiguos construidos en terrenos arcillosos. Doctoral Thesis. Univ. Autónoma de Madrid.
Regadío, M., Ruiz, A.I., de Soto, I.S., Rodriguez Rastrero, M., Sánchez, N., Gismera, M.J., Sevilla, M.T., Rodríguez Procopio, J., Cuevas, J., 2012. Pollution profiles and physicochemical parameters in old uncontrolled landfills. Waste Manage. 32, 482-497.

Rhoades, J.D., 1982. Cation exchange capacity. In: Miller, A.L., Keeney, D.R. (Eds.) Methods of Soil Analysis, Chemical and Microbiological Properties. Soil Sci. Soc. Am. Madison, pp. 149-157.

Rogel, J.M., Leguey, S., Santamaría, J.M., Cuevas, J., Muñoz, E., Garrido, A., Avellanosa, P., Hervás, J., Sevilla, M.T., Procopio, J.R., 2009. Proyecto de investigación y desarrollo sobre la evaluación del comportamiento de arcillas frente a lixiviados de vertederos urbanos. Exp. 106/2004/2. In: Subvenciones de i+d+i en el ámbito de la prevención de la comtaminación. Balance 2004-2007. Centro de publicaciones, Ministerio de Medio Ambiente. Madrid, pp. 56-32.

Rolle, M., Prabhakar, C., Rajandrea, S., Di Molfetta, A., 2008. A kinetic approach for simulating redox-controlled fringe and core biodegradation processes in groundwater: model development and application to a landfill site in Piedmont, Italy. Hydrol. Process. 22, 4905-4921.

Rosanne, M.M.N., Koudina, N., Prunet-Foch, B., Thovert, J.F., Tevissen, E., Adler, P.M., 2003. Transport properties of compact clays. II. Diffusion. J. Colloid Interface Sci. 260, 195-203.

Rowe, R.K., 1989. Movement of Pollutants through Clayey Soil. Ann. Geotechnical Conf. Minnesota Section ASCE, St. Paul, pp. 1-34.

Rowe, R.K., Quigley, R.M., Booker, J.R., 1995. Clayey Barrier Systems for Waste Disposal Facilities. Spon Press, Abingdon, Oxon.

Saaltink, M.W., Battle, F., Ayora, C., Carrera, J., Olivella, S., 2004. RETRASO, a code for modeling reactive transport in saturated and unsaturated porous media. Geol. Acta 2, 235-251.

Schultz, L., 1964. Quantitative Interpretations of Mineralogical Composition from Xray and Chemical Data for Pierce Shale. US Geol. Surv. Prof. Paper 391C.

Smith, D., Pivonka, P., Jungnickel, C., Fityus, S., 2004. Theoretical analysis of anion exclusion and diffusive transport through platy-clay soils. Transport Porous Media 57, 251-277.

Spooner A.J., Giusti, L. 1999. Geochemical interactions between landfill leachates and sodium bentonite. In: Metcalfe, R., Rochelle, C.A. (Eds.), Chemical Containment of Waste in the Geosphere. Geological Society, Special Publication 157, pp. 131-142.

Srodon, J., Drits, V.A., McCarty, D.K., Hsieh, J.C.C., Eberl, D.D., 2001. Quantitative Xray diffraction analysis of clay bearing rocks from random preparations. Clays Clay Miner. 49, 514-528.

Tanhua-Tyrkkö, M., 2009. Modelling Hydrological and Chemical Phenomena during Interaction of Bentonite and High pH Plume. MSc Thesis. Univ. Jyväskylä, Finland.

Thomas, W.G., 1982. Exchangeable cations. In: Miller, A.L., Keeney, D.R. (Eds.), Methods of Soil Analysis. Soil Sci. Soc. Am. Part 2, pp. 159-165.

Thornton, S.F., Tellam, J.H., Lerner, D.N., 2000. Attenuation of landfill leachate by UK Triassic sandstone aquifer materials. 1. Fate of inorganic pollutants in laboratory columns. J. Contam. Hydrol. 43, 327-354.

Van Loon, L.R., Glaus, M.A., Muller, W., 2007. Anion exclusion effects in compacted bentonites: towards a better understanding of anion diffusion. Appl. Geochem. 22, 2536-2552.

VanGulck, J.F., Rowe, R.K., 2004a. Evolution of clog formation with time in columns permeated with synthetic landfill leachate. J. Contam. Hydrol. 75, 115-139.

VanGulck, J.F., Rowe, R.K., 2004b. Influence of landfill leachate suspended solids on clog (biorock) formation. Waste Manage. (Oxford) 24, 723-738.

Zhang, F., Xu, H., Konishi, H., Roden, E.E., 2010. A relationship between d104 value and composition in the calcite-disordered dolomite solid-solution series. Am. Mineral. 95, 1650-1656. 